\title{
Perceived Meanings by Women and Men Employees Analysis of Thailand Life Insurance Commercial "Silence of Love"
}

\author{
Aditya Putri Goentoro \\ English Department, Faculty of Letters, Petra Christian University, Siwalankerto 121-131, \\ Surabaya 60236, INDONESIA \\ E-mail: m11416040@john.petra.ac.id
}

\begin{abstract}
Advertisement is one of the ways that are still popularly used by various companies in creating brand awareness of the products they want to sell. In this study, the writer wanted to find out the differences and similarities in men and women's perceived meanings of the verbal and visual expressions in the Thailand Life Insurance advertisement titled "Silence of Love". The writer using the semiotic analysis tools of connotation and denotation. From the study, the writer found that both respondents focused on the plot because of the broad image and the message the company conveyed. However, both respondents had heightened emotional intensity which made them remember that the ad is from a specific Thailand insurance company.
\end{abstract}

Key Words: Advertisement, Semiotics, Life Insurance, Verbal and Visual Expressions

\section{INTRODUCTION}

A good product needs good advertising. Advertisement is one of the main tools for companies to reach their target market. In business communication, advertisement is an essential part to create brand awareness for the audience. To bring out their product to the world, brands need to introduce them by communicating it through one or other ways, one of which is advertisement. By using advertisements, they could reach widder audience and create bigger awareness about their product. However, to catch a new customer's attention, brands need to put a lot of effort into advertising. An advertisement is a powerful tool for a company to communicate a message to the audience. As advertisement distribution becomes easier nowadays, companies are mostly competing in the field of digital advertising.

In the past, people used television or radio as their media platform to distribute ads. However, today's technology is centered in social media, because it is commonly used by the people. Therefore, to get the audience to be interested in buying the product, the ad maker needs to create an attractive advertisement, for example, a video commercial which relates into the audience's reality without decreasing the product's value. Studies show that people rely on emotions, rather than information, to make brand decisions - and that emotional responses to ads are more influential on a person's intent to buy than the content of an ad. (Praet, 2014). Take the example of Coca-Cola, a big company which employs a specific marketing strategy to emotionally connect to their customers: \#choosehappiness. To share the happiness, Coca Cola put their vending machine in a college, and any students who bought a drink from that machine may get surprised, such as receiving a lot of Coca Cola bottles or even flowers, and they will be happy to receive them.

According to study from Deng, Chang, Yang, Huo, \& Zhou (2016), there are different ways between men and women to express their emotions. When watching a horror video, women had lower valence, higher arousal, and stronger avoidance than men did. Women also reported having higher arousal when watching videos that induced sadness. The findings suggest that, when watching videos that induce an emotional response, men often have more intense emotional experiences, whereas women have higher emotional expressivity, particularly for negative emotions. One of the advertisements which the writer chose as a successful 
advertisement which engaged a lot of audiences is "Silence of Love". It is a life insurance ad which has been watched by over 8 million people on YouTube. In relation to the writer's research on the differences of perceived meaning between men and women towards an emotional ad, the writer choose Cheskee's employees. The writer noticed that some of the employees do not have insurance to support themselves. Thus, the object of the research, a Thailand insurance ad, is perfect for this purpose.

\section{REVIEW OF RELATED LITERATURE}

The writer use two theories, process of signification and perceived meanings. First of all, semiotics is a study of not only sign in everyday speech, but also of anything that stands for something else (Chandler, 2007). In the process of signification, denotation referred as the first order signification. Denotation definitions which are accepted by the language group as a whole, or the dictionary definition of a word. Denotation described as the definitional, 'literal', 'obvious' or 'commonsense' meaning of a sign (Chandler, D. 2007, p137). For example, a word cowboy is a man who takes care of cattle. Another denotation is a reckless and/or independent person. The next signification level that explains between signifier and signified is connotation. Connotation refers to definitions that are based on emotion-or-experience-based associations people have with a word. For example, the word change can have positive or negative connotations depending on a person's experiences (Chapter 3 Verbal Communication., 2012). Connotation's scope in interpreting an object is wide. Its goal is to find hidden meanings from a text, picture, symbol, and even what a person does.

Second, perceived meanings is a part of Semiotics. According to Tomaselli (1996), perceived meanings is one's way to interpret and explain a sign. A semiotic analysis provides a way to connect a text to the message system where it operates. This gives intellectual context to the content: semiotics explains how different parts of a text work together and interact with cultural knowledge to create meaning. According to Stuart Hall (1973), in his theory of televisual communication (related to media discourse), a process of communication in the form of encoding and decoding happens when an ad is aired. Encoding is a process in which the encoder turns thoughts into communication by using mediums such as ad. Then, the audiences (decoders) receive the message and interpret the encoder's idea into thoughts. However, each decoder's interpretation may result in different meanings. For example: A (encoder) asks his friend, B (decoder), to turn off the fan, which B then receives and processes into a thought, and then, action.

\section{METHOD}

The approach that the writer used in analyzing the data is descriptive qualitative approach, since this research aims to describe the perceived meanings of Thai Life Insurance ad "Silence of Love". To be more detailed, the writer would use a descriptive approach, since the writer would analyze the perceived meanings from men and women employees. Qualitative approach is suitable for this research since the writer wants to find out the individual interpretation from both verbal and non-verbal expressions in the advertisement. Data for this study were taken from Youtube's video titled "Silence of Love". In the analysis, the writer transcribes the dialogue then categorizes them into verbal and visual expressions. Verbal communication is based on utterances (including subtitles and sign language), whereas visual expressions is based on the actors' facial expressions and gestures.

\section{FINDINGS AND DISCUSSION}


Goentoro: Perceived Meanings by Women and Men Employees Analysis of Thailand Life Insurance Commercial "Silence of Love"

The writer started the analysis by analyzing the female respondents by providing questions. The female respondents were classified as Respondents 1 to 5 (R1-R5) and for male respondents were classified as Respondents 6 to 10 (R6-R10). As the writer analyze the answers from both group it was found out that there are similarities and differences when perceiving the meanings towards the advertisement. In fact, it is known that this advertisement is not explicitly explaining the products they offer. In this case, the writer will compare between male and female respondents' perceived meanings. The writer will provide a table which will be used to group the similarities and the differences from verbal and verbal expressions analysis below:

\begin{tabular}{|c|c|c|}
\hline \multirow[t]{2}{*}{ Similarities } & \multicolumn{2}{|l|}{ Differences } \\
\hline & Females & Males \\
\hline $\begin{array}{l}\text { - Needed to be fit into } \\
\text { social and economic } \\
\text { standard. } \\
\text { - Have sense of security } \\
\text { and positivity } \\
\text { - Feeling competitive } \\
\text { when it comes to their } \\
\text { relation with others }\end{array}$ & 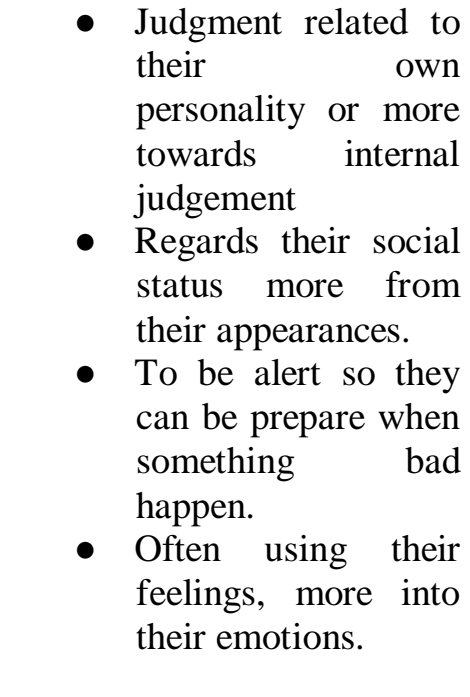 & $\begin{array}{l}\text { - Prefer how they } \\
\text { can be useful or } \\
\text { judge things } \\
\text { from the outside } \\
\text { perspective } \\
\text { - Instinctively } \\
\text { have a sense of } \\
\text { being someone } \\
\text { who can be } \\
\text { trusted, they } \\
\text { feel more like } \\
\text { protecting } \\
\text { Tend to be more } \\
\text { logical when } \\
\text { reading a } \\
\text { situation }\end{array}$ \\
\hline
\end{tabular}

From the analysis, it can be seen that male and female respondents have similarities and differences in perceiving the meaning. First, the authors found that the similarities of both respondents were that they had a need to be accepted in social and economic standards. This is because their view of social standards is an important point for them to survive, which is related to the lifestyle of a person in this day and age that is beginning to develop. The need to be accepted by the community plays an important role in the progress of their lives, as well as social standards become the benchmark for them to get a job and in connecting with others. This is supported by the respondents' answers, who stated that by being accepted in their societies, it will be easier for them to get a job and have friends, as shown in the ad.

Second, male and female respondents have a similar wish to have a secure, positive life. The writer found out that, by instincts, they want a life unhindered by disturbances such as illness and other things that can disturb their peaceful life - this is related to their own personal experiences.

Third, another similarity that the writer found is that in how they communicate with strangers - they will feel competitive, which is caused by their life condition as Cheskee employees. Their background experiences affect how they see the ad.

However, the writer had also found out differences in the respondents' judgement behavior. For one, female respondents are more likely to judge something based on their inner reflections and judgements; they also judge someone's appearance in assessing their social status; and lastly, females have a tendency to be on guard in certain situations (because they are 
seen as weaker than men. From this, the writer concluded that they feel the need to always be careful, even though their lives were very well maintained and fine. The writer also found a relation to a previous study by Deng, Chang, Yang, Huo, \& Zhou (2016): in judging something, females tend to use their emotional feelings and they also tend to be more expressive in expressing their judgment. In the context of this research, the writer found that female respondents were able to connect their responses with their personal experiences and that they detail their emotional experiences clearer than male respondents.

Furthermore, for male respondents, they prefer how they can be useful or judge things from the outside perspective. Instinctually, they also have a sense to protect others and they want to be seen as reliable person. Male respondents also used their logic more in analyzing a situation. An example, just like there is a part of the advertisement where the father wants to give his property to his daughter, they consider it necessary to look back at the situation and not rashly give something even though his daughter is the most valuable treasure. This is a proof of the statement in Deng, Chang, Yang, Huo, \& Zhou (2016)'s study, that males are more intense, but their expression does not match their intensity.

In an analysis of respondents' answers, the authors found that this insurance advertising strategy refers less to the business they want to embed in the ad, but it is found that some respondents understand that the message conveyed from this ad is that they want to offer its protection products through events they showed in the story plot. As the writer explained previously, they managed to create a memory in their audiences mind of the importance of having insurance and implicitly they want the audience to recognize the advertising company through emotional interaction with the audience. This ad has been watched by millions of people, and some people will still remember this ad because of their exmotional experience when they see this Thailand Life Insurance "Silence of Love" ad.

\section{CONCLUSION}

In her findings, the writer found that this advertisement describes a relationship between a father and his daughter. Broadly speaking, this advertisement has a broad relationship with the commercial objectives of its advertisement which is found in the analysis of respondents. However, although not all respondents can clearly understand the relationship between the picture and their product, they can understand the idea that they want to convey to their audience, which is the role of insurance that they want to show through this short video. The writer finds that female respondents tend to look at and judge from the inside describing how they want and protect themselves, while male respondents tend to judge what can be done to others, such as how they try to take care of those around them. The differences and similarities in the results of perceived meanings of women and men were related to their emotional intensity about how they perceive the future.

So in this case, a person's emotional role can have an effect in producing their perceived meanings. The writer can conclude that the broad description of the advertisement "Silence of Love" with its relation to their product influences how they view whether their product is accountable or not. Also the existence of stereotype towards people with disabilities was also found to influence how they view these advertisements. The writer hopes that this writer's writing is beneficial for future research for students who do research in the field of semiotics, especially perceived meanings related to marketing communication fields. 
Goentoro: Perceived Meanings by Women and Men Employees Analysis of Thailand Life Insurance Commercial "Silence of Love"

\section{REFERENCES}

Ahmed, S., \& Ashfaq, A. (2013). Impact of advertising on consumers buying behavior through persuasiveness, brand image, and celebrity endorsement. Global Media Journal Vol(6) $\mathrm{No}(2)$.

Chandler, D. (2007). Semiotics: The basics (2 $2^{\text {nd }}$ ed). London: Routledge.

Deng, Y., Chang, L., Yang, M., Huo, M., \& Zhou, R. (2016). Gender differences in emotional response: Inconsistency between experience and expressivity. Plos One $\operatorname{Vol}(11)$, No(6).

Fischer, A. H., Kret, M. E., \& Broekens, J. (2018). Gender differences in emotion perception and self-reported emotional intelligence: A test of the emotion sensitivity hypothesis. Plos One Vol(13), No(1).

Kurniawan, Fransisca T. (2017). Perceived meanings by women and men in "identical twins and best friends" olay advestisement. Surabaya.

Macauley, R., \& Quartz (2015). Thai commercials: Great at making people cry. Boston: The Atlantic.

Muttaqien, Z. (2011). The denotative and connotative meanings in the axe-advertisements. Jakarta: UIN Syarif Hidayatullah.

Rifa'i, B. (2010). A semiotic analysis on coca cola's commercial advertisements. Jakarta: UIN Syarif Hidayatullah 
